\title{
Edebiyatımızda Kaside-i Münferice Geleneği ve Ebu Bekir Kânî'nin Manzum Kaside-i Münferice Tercümesi a
}

\author{
İlyas Yazar b
}

\section{Özet}

Belli bir amaçla söylenmiş, üzerine düşünülmüş, gözden geçirilmiş şiir manasında terim anlamıla kullanılan kaside, Arap edebiyatında ortaya çıkmış ve oradan İran ve Türk edebiyatlarına geçmiş bir türdür. Arap edebiyatında pek çok örneği olan bu tür eserlerden İslam âleminin ortak duygu ve düşüncelerini terennüm edenlerinin geçen zamana nispetle sadece Araplara mahsus kalmadığını, tüm Müslümanların ortak malı haline dönüştüğü tarihsel açıdan da bilinen bir gerçektir. Bu tür eserlerden biride XI. yüzyılda yaşamış olan Tunuslu meşhur âlim ve şair İbnu'n-Nahvî'nin “elKasidetü'l-Münferice" adlı kasidesidir. Yüzyıllardır İslam dünyasında özellikle sıkıntı ve darlık içinde bulunanlar tarafından okunmasının bir gelenek haline dönüşmesiyle karşılık bulan kasidenin başta Arap, İran ve Türk olmak üzere müşterek İslam edebiyatlarında pek çok şerhi, tahmisi, taştiri ve taklitleri bulunmaktadır. Kaside-i Münferice'nin manzum tercümelerinden birisi de XVIII. Yüzyıl şairlerinden Ebu Bekir Kânî’ye aittir. Bu çalışmada Münferice Kasidesi ekseninde oluşan edebi gelenekten hareketle Ebu Bekir Kânî'nin manzum Kaside-i Münfericesi değerlendirilmiştir.
Anahtar Kelimeler

Kaside-i Münferice

İbnu'n-Nahvî

Ebu Bekir Kânî

İslâm Edebiyatı

Makale Hakkında

Geliş Tarihi: 12.10.2019

Kabul Tarihi: 13.03.2020

Doi: 10.18026/cbayarsos.632360

\section{Kaside-i Münferice Tradition in Turkish Literature and Translation of Abu Bakr Kânî's verse Kaside-i Münferice}

\begin{abstract}
It is a poetry of praise, which is sung for a certain purpose. It is a genre that emerged in Arabic literature and passed on to Iranian and Turkish literature. It is known that some of the kasides, which have many examples in Arabic literature, form a common language of poetry in Islamic literature. One such work is XI. It is the poem named al-Kasiîdetü'l-Münferice sung by Ibn'nNahvî, the famous Tunisian scholar and poet who lived in the 16th century. It has been read by those who have been in distress and stenosis in the Islamic world for centuries and its reading has become a tradition. Kaside-i Münferice has many commentaries, prediction, stone and imitations in the common Islamic literature, especially in Arabic, Iranian and Turkish. One of the verse translations of Kaside-i Münferice is XVIII. It belongs to Abu Bakr Kânî, one of the 18th century poets. In this study, the translation of Abu Bakr Kânî's verse Kaside-i Münferice is emphasized on the basis of literary tradition formed on the axis of Münferice.
\end{abstract}

Keywords

Kaside-i Münferice

Ibnu'n-Nahvî

Abu Bakr Kânî

Islamic Literature

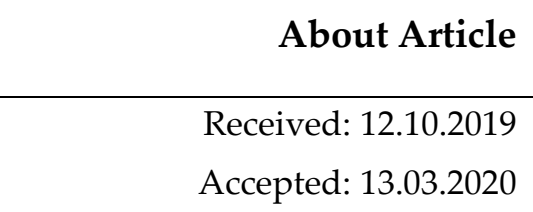

Doi: $10.18026 /$ cbayarsos.632360

\footnotetext{
a Bu makale Haluk İpekten Anısına Düzce Üniversitesi tarafından düzenlenen Klâsik Türk Edebiyatının Ses ve Anlam Dünyası Sempozyumunda sunulan sözlü bildiriden üretilmiştir.

b Doç. Dr., Dokuz Eylül Üniversitesi Buca Eğitim Fakültesi Öğretim Üyesi, iyazar@gmail.com, ORCID ID: 0000-0002-6784-289X
} 


\section{Giriş}

Sözlükte kastetmek, niyet etmek, yaklaşmak anlamlarında Arapça "kasada" kökünden türemiş bir kelime olup bir kişiyi övmek ve genellikle karşılığında yardım istemek için yazılan şiirlerin adı olan kaside, ilk defa Arap edebiyatında ortaya çıkmış, oradan Fars ve Türk edebiyatlarına geçmiş bir türdür. Hem bir nazım şekli hem de bu nazım şekliyle yazılan türün adı olarak da bilinen kasidenin gerek biçimsel gerekse muhteva açısından standardize edilmiş bir forma sahip olduğu malumdur. Arap edebiyatında yazılmış, meşhur olmuş ve zaman içinde bütün Müslümanların ortak duygularını dile getirdiği için sadece Arapların değil her milletten Müslümanların ortak malı haline gelmiş başta Kaside-i Bürde olmak üzere Kaside-i Münferice, Kaside-i Bânet Su'âd, Kaside-i Tantarâniyye, Kaside-i Hamriyye, Kaside-i Tâiyye gibi bazı kasidelerin XIV. yüzyıldan itibaren Türk edebiyatında da manzum ve mensur şerhlerinin yazılmaya başlandığı ya da bu tür eserlere ilham vererek kaynaklık ettiği anlaşılmaktadır.

\section{1. İbnü'n-Nahvî Hakkında}

Çalışmamızın özünü teşkil eden Kaside-i Münferice de bu bağlamda Türk edebiyatında yakından tanınan ve üzerinde birçok Türkçe tercüme, şerh ve tahmis türü çalışmaların yapıldığ1 manzumelerden birisi olmuştur. Bu bakımdan öncelikle Kaside-i Münferice şairi İbnü'n-Nahvî'ye kısaca değinmek yararlı olacaktır. Tunuslu bir şair olan İbnü'n-Nahvî edebiyatçı, dilci, nahivci, kelamcı, fakîh ve mutasavvıf kimliğe sahip bir kişi olup tam adı Yûsuf b. Muhammed b. Yûsuf et-Tevzerî'dir. Künyesi Ebü'l-Fadl olmakla birlikte İbnü'nNahvî adıyla tanınmıştır. İbnü'n-Nahvî, Güneybatı Tûnus'ta bir şehir olan Tevzer'de 433/1041'de doğmuş, eğitimine Tevzer'de başlayarak Tevzer'in önde gelen şair, fıkıhçı ve hadis âlimlerinden Ebû Zekeriyyâ Abdullâh b. Muhammed eş-Şakratisî' den dersler almış, ardından Tunus'un Safâkus şehrine giderek "el-Lahmî" adıyla maruf Alî b. Muhammed erRabaî'nin derslerine devam etmiştir. Bu dönemde el-Lahmî'nin "et-Tabsire" adlı kitâbını istinsâh etmiş ve ondan Sahîhü'l-Buhârî'yi rivayet etmiştir. Nahvî'nin eğitim hayatına ilişkin olarak Kayravan'a da gittiği ve orada bazı âlimlerden ders alarak tahsil hayatını tamamladığı da rivayet edilmektedir. Nahvî, eğitim hayatını tamamladıktan sonra Tunus' ta nahiv dersleri vermeye başlamış, hayatının belirli dönemlerinde Sicilmase ve Fas'ta bulunmuşsa da büyük bölümünü Bicâye yakınlarındaki Benî Hammad Kalesi'nde geçirmiş ve 513/1119 tarihinde burada vefat etmiştir (Alzyout, 2013:4). İbnü'n-Nahvî'nin hacca gittiği ve bu arada Mısır'1 ziyaret ettiği de yazdıklarından anlaşılmaktadır (Elmalı, 2002: 39).

İbnü'n-Nahvî'nin tahsil hayatını tamamlamasından sonra kendisini ilme adadığı ve başta nahiv olmak üzere çeşitli dersler verdiği, derslerinden herhangi bir ücret talep etmediği, geçimini Tevzer'deki bir çiftliğin gelirinden temin ettiği, fıkıh konusundaki görüşleri ve içtihatlarıyla toplum nazarında temayüz ettiği, ilmi ve ameli açısından Gazâlî́ye denk görüldüğü ve bazı çevrelerce de keramet sahibi bir veli olduğuna inanıldığına dair hakkında yazılan kaynaklarda çeşitli bilgiler nakledilmiştir (Elmalı, 2002: 40).

\section{Eserleri}

Kaynaklarda eserlerine pek değinilmemiş olan İbnü'n-Nahvî'nin kayıtlı iki eseri bulunmaktadır. Bunlardan biri Brockelman'ın bir nüshasının Berlin 3981'numarada kayıtlı 
"el-Vasiyyet"; diğeri de bu çalışmamızla ilişkili bulunan "el-Kasidetü'l-Münferice" adlı eseridir (Elmalı, 2002: 40).
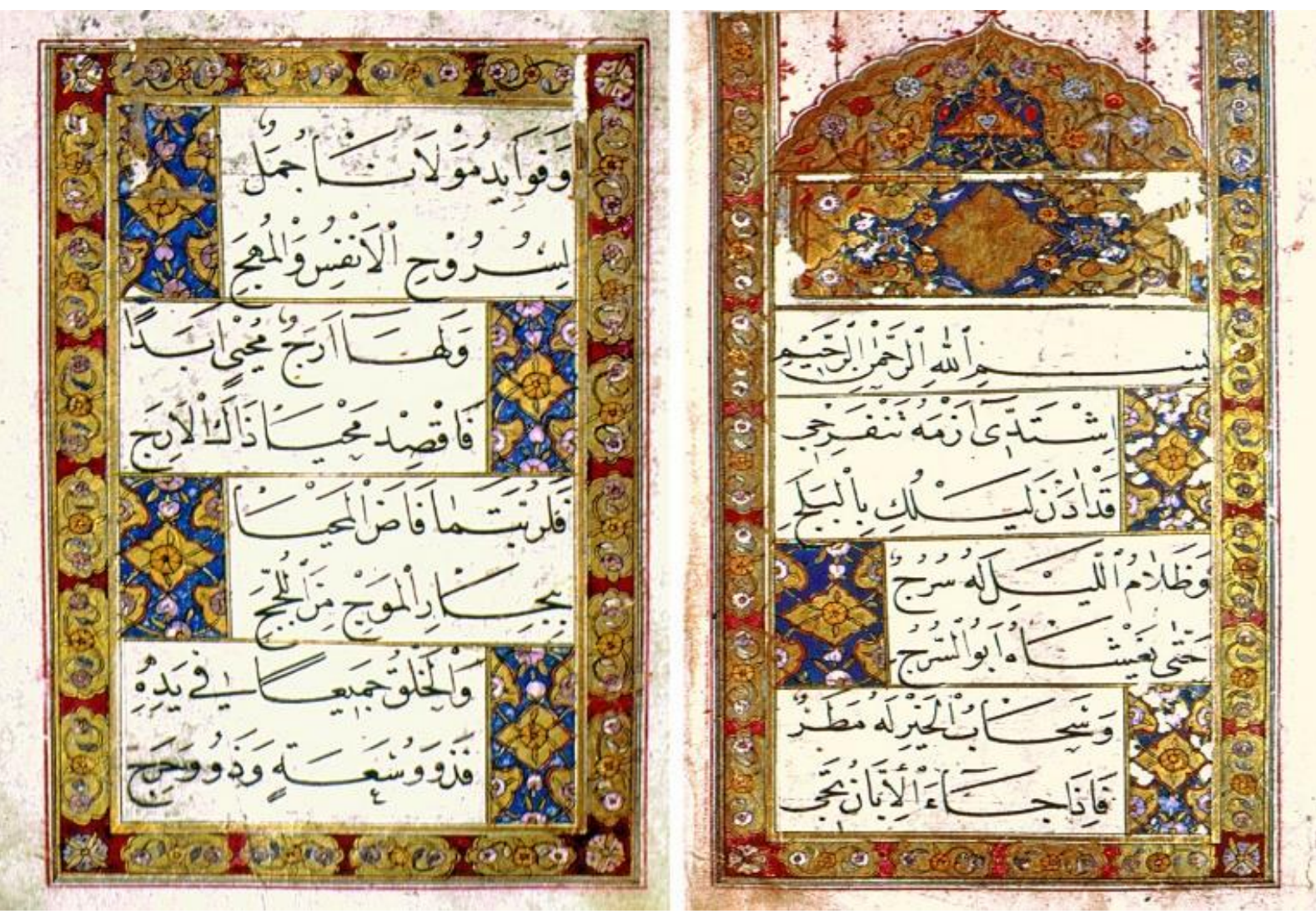

Resim1: İbnü'n-Nahvî'nin el-Kasîidetü'l-münferice'sinin ilk iki sayfası (Süleymaniye Ktp.,Reşid Efendi, nr.519/7)

(Kaynak: https://islamansiklopedisi.org.tr/ibnun-nahvi)

\section{Kaside-i Münferice}

Kaside-i Münferice ile ilgili anlatılanlara ve aktarılan rivayetlere bakıldığında İbnü'nNahvî'nin Tevzer dişındayken zorbalar tarafından malının gasp edilmesinin duyulması üzerine bu kasidenin inşad edildiği; kasidenin inşadından sonra da malını gasp eden kişinin o gece rüyasında birisinin süngü ile üzerine yürüdüğünü gördüğü ve "falancanın malını vermezsen seni öldüreceğim" dediğini, bunun üzerine uykusundan korkuyla uyanan kişinin gasp ettiği malı geri götürüp iade ettiğine dair anlatılar öne çıkmaktadır. Esas itibarıyla Allah'a teslimiyetin, bağlllığın ve O'na güvenin terennümü olan Kaside-i Münferice, başta tasavvuf çevreleri olmak üzere Arap ve İslam edebiyatlarında adından sıkça söz ettiren Ka'b b. Züheyr (26/645)'in Hz. Peygambere sunmuş olduğu Kaside-i Bürde'nin sahip olduğu şöhrete yakın bir üne kavuştuğu da ileri sürülmektedir (Elmalı, 2002:41).

\subsection{Yayılmasi}

Kaside-Münferice'nin halk nezdindeki itibarının giderek artması ve özellikle de dini-tasavvufi çevreler tarafından geniş kabul görerek bir vird şeklinde okunmaya başlanması gibi yaygın ritüeller sonucu kasidenin bazı dua mecmualarına girdiği de anlaşılmaktadır. Ayrıca kasidenin İsm-i A'zam'ı içerdiği ve dua niyetiyle okuyanın dualarının kabul olacağına yönelik 
oluşan inanç silsilesi de bu bağlamdaki ritüelleri desteklemiş ve insanlar sıkıntılarından kurtulmak ve arzularına kavuşmak için Kaside-i Münferice okumayı âdet edinmişlerdir (Elmal1, 2002:41).

Kaside-i Münferice'nin yaygınlaşmasında âdet haline gelen yaklaşımlarla ilgili kasidenin önemli şârihlerinden İsmail Ankaravî de, büyük şafi âlimi ve fakihi İmam Takiyyüddin esSübkî'nin de kendilerine her hangi bir keder ve sıkıntı isabet ettiğinde bu kasideyi okuduğunu, ayrıca kendisine her hangi bir sıkıntı ya da bela isabet eden bir kimsenin maddimanevi tam bir temizlik ile kırk kez bu kasideyi okuyarak yüce Allah'a dua ederse yüce Allah'ın onun duasını kabul edeceğini ve sıkıntı ve ihtiyaçlarını gidereceğini söyleyerek bu kasidenin okunmasını tavsiye ettiğini belirterek bizzat kendisinin görüştüğü birçok büyük zatın da bu kasidenin nice özelliklerinden ve faydalarından kendisine bahsettiğini, özellikle bu kasidenin güzel manalarına ve yüce nüktelerine vakıf olarak okuyan kimsenin gönlünün genişleyeceğini, derununun rahata kavuşacağını ifade etmektedir (Çakmaklığlu, 2017:465).

Kaside-i Münferice, ayrıca İslam mimarisinde de karşıllk bulmuştur. Antalya Kaleiçi'nde XVII. yüzyıl başında Tekeli Mehmet Paşa tarafından tamamen kesme taş işçiliği ile yaptırılan camiinin işçilik ve estetik güzellikleriyle dikkat çekmesinin yanında diğer camilerden ayrılan en önemli özelliğinin iç ve dış pencere alınlıklarının çini panolarında yer alan ve kırk beytin tamamının yazılı olduğu Kaside-i Münferice metnidir (Atik, 2018:15).
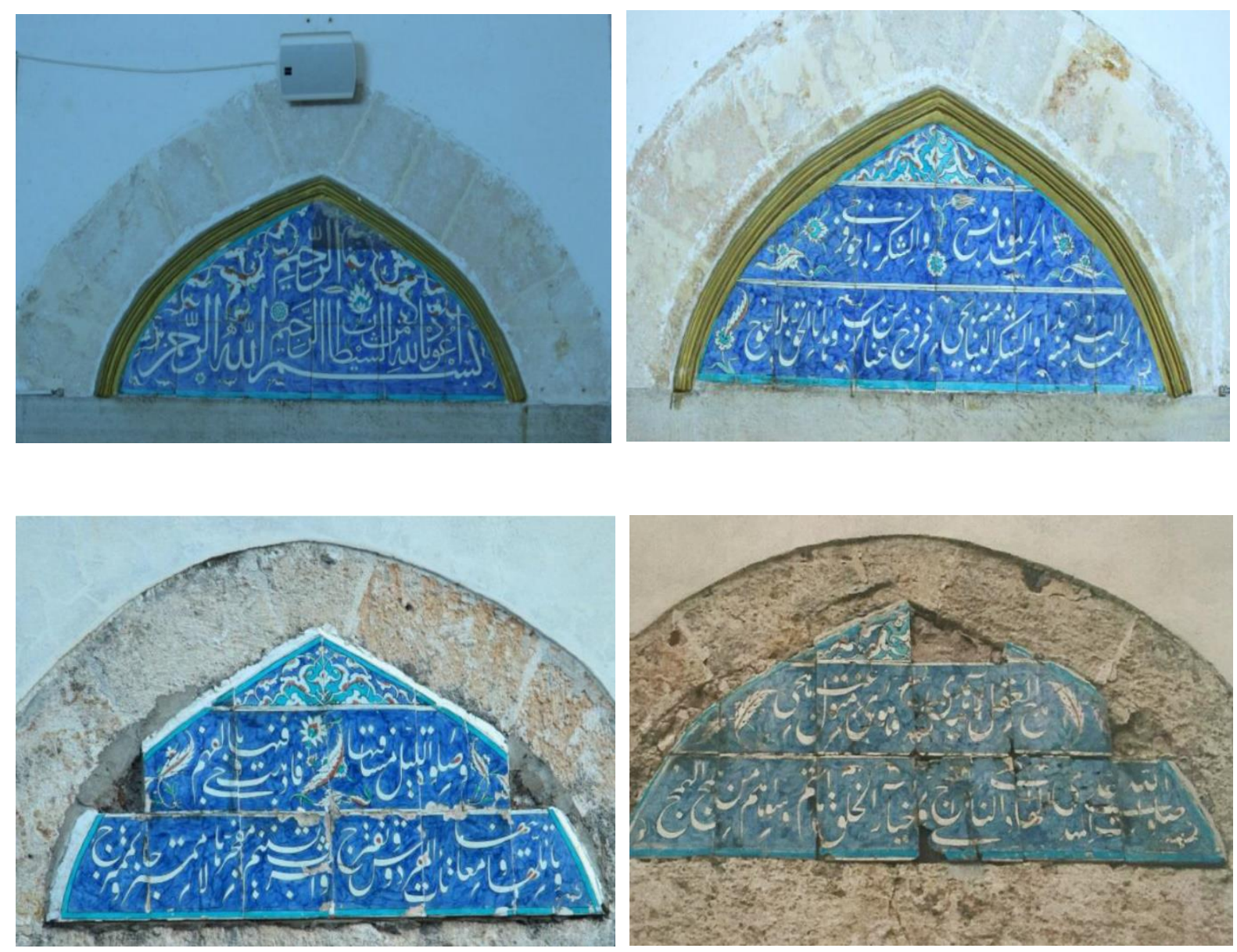

Resim2: Atik, 2018:43-47 


\section{2. Özellikleri}

el-ferec, el-fütûh, el-münferice, ümmü'l-ferec, $b a^{\prime} d e^{\prime}$ ş-şidde gibi adlarla da bilinen Kaside-i Münferice, feilün tef'ilesinin her beyitte sekiz tekrarından oluşan mütedarik (habeb) bahirle yazılmış toplam kırk beyitlik bir şiirdir. Ancak şerh ve tercümelerinde beyit sayısının elliye kadar çıktı̆̆1 da görülmektedir. Arapça ve Farsça şerhleriyle birlikte İstanbul (1290, 1302), Bombay (1299), Bulak (1303) ve İskenderiye (1304)'de birçok kez basılan kasidenin tercüme, şerh ve tahmisleri yapılmış, Türk edebiyatında da yakından tanınmış, müellifi bilinen ya da bilinmeyen birçok Türkçe tercüme, şerh ve tahmis türü çalışmalara konu olmuştur (Yıldırım, 2015: 89-92).Türkçe şerhleri arasında en meşhur olanı İsmail Rusûhî Ankaravî'nin yazmış olduğu el-Hikemü'l-Minderice adlı şerhidir (Çakmaklığu. 2017:465). Ayrıca konuyla ilgili çalışmasında Hüseyin Elmalı da, Kaside-i Münferice bağlamında oluşan edebi gelenekle ilgili değerlendirmesinde Münferice kasidesinin 9 şerhi, 11 tahmisi yanında çok sayıda tercümesinin bulunduğundan söz etmektedir (Elmalı, 2002: 45-50).

İslam dünyasında mimariden edebiyata, şiire ve güzel sanatların farklı alanlarına kadar oldukça geniş bir yelpazede karşılığı bulunan ve insanların sıkıntılı anlarına ferahlık getireceğine inanılan Kaside-i Münferice'nin Türkçe manzum tercümelerinden biri de XVIII.yy. şairlerinden Ebu Bekir Kânî’ye aittir.

\section{Ebu Bekir Kânî'nin Manzum Kaside-i Münferice Tercümesi}

Ebu Bekir Kânî XVIII. yüzyılın nazım ve nesir sahasının önde gelen isimlerinden birisi olup 1712 yılında Tokat'ta dünyaya gelmiş, ilk eğitimini Tokat'ta tamamlayan şair, genç yaşta şiirle ilgilenmeye başlamış ve nükteli söyleyişleriyle adını duyurmuştur. Gençlik yıllarının bunalımlı dönemlerinde Mevlevi şeyhi Abdülahad Dede'ye intisap ederek 39-40 yaşlarına kadar Tokat Mevlevihanesine devam etmiştir. Şiirdeki asıl şöhretine 1168/1755'te Hekimoğlu Ali Paşa'ya kendisini kanıtlayıp onunla İstanbul'a gittikten sonra ulaşmıştır.

İstanbul'da önce Dîvân-1 Hümâyûn kaleminde eğitime başlamış ve kısa sürede eğitimini tamamlayarak "Hâcegân-1 Dîvân-1 Hümâyûn" pâyesine sahip olmuştur. İstanbul'a gelmesinde katkısı olan Ali Paşa'nın 1755'te Silistre'ye gönderilmesi üzerine Paşa'ya eşlik etmiş ve onun hizmetinde bulunmuş, daha sonra Paşa'nın yanından ayrılarak Eflak, Rusçuk ve civar bölgeleri gezmiş, dolaştığı bölgelerde eşrafla dostluklar kurmuş, Ulah beylerinin kâtipliklerini yapmış, Sadrazam Yeğen Mehmed Paşa'nın daveti üzerine 1782 yılında tekrar İstanbul'a dönmüş ve 1206/1791'de İstanbul'da vefat etmiştir (Yazar, 2010: 34-43). Başta Divan'ı olmak üzere Münşeat, Letaif ve Benâm-1 Havariyyun gibi eserleri de bulunan Kânî'nin manzum Kaside-i Münferice tercümesi divanında yer alan manzumelerden biridir.

Kânî Divanı'nda kâsâid bölümünde 22. kaside olarak yer alan Kaside-i Münferice 43 beyitten mürekkeptir. Nahvî'nin kasidesini manzum şekilde Türkçeye aktaran Kânî, kasidenin orijinaline üç beyit ilave etmiştir. İlave beyitlerin ilkinde Hz. Fatıma, Hz. Hasan ve Hz. Hüseyin için salât ü selam; ikincisinde hak yolunda canları ve mallarıla mücadele edenler için dua; son beyitte ise sıkıntı ve elemlerden kurtulma niyazı ve Allah'ın yardımı talep edilmektedir. 


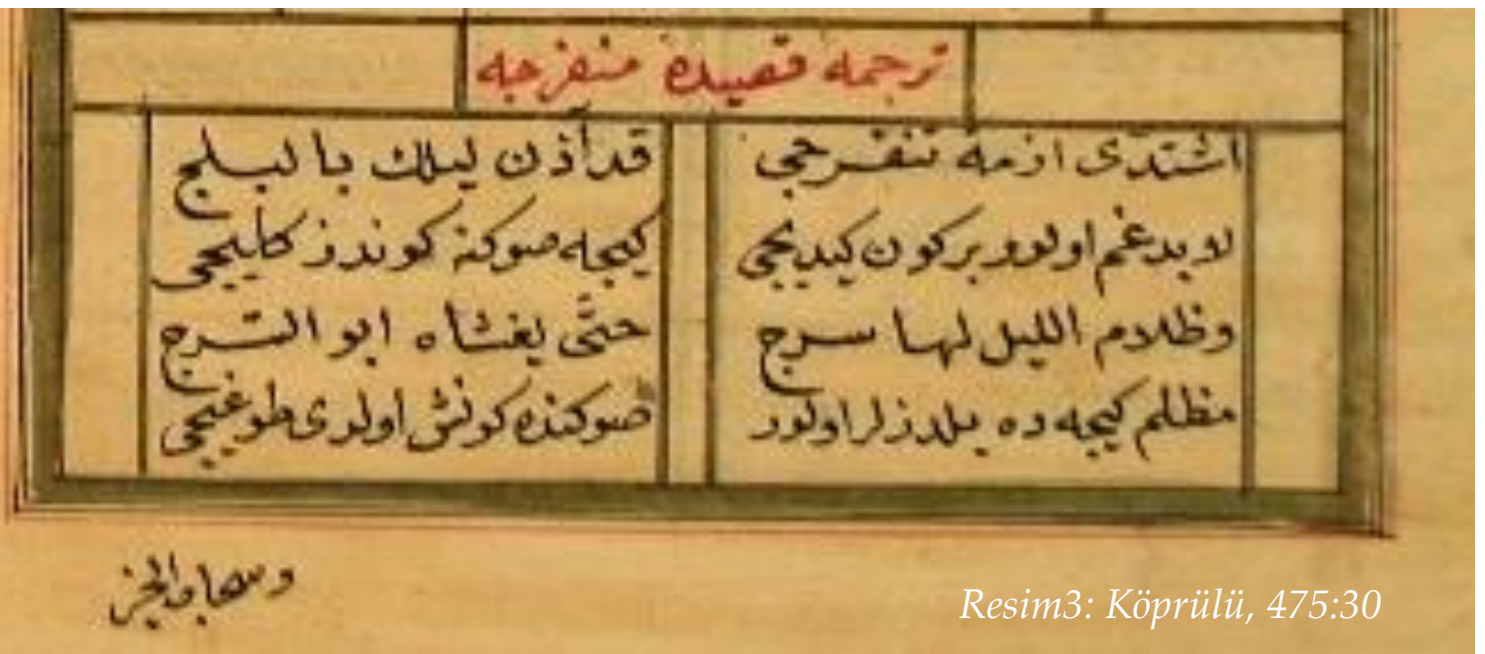

\section{Kaside-i Münferice'nin Muhtevası}

Çalışmanın sonunda ek olarak transkripsiyonlu orijinal metni, manzum çevirisi ve diliçi çevirisinin bir arada tablo halinde verildiği Kaside-i Münferice tercümesinde besmele ile başlanan kasidenin önce Arapça metni verilmiş, ardından her beytin altında kasidenin Türkçe tercümesi yapılmıştır. Ebu Bekir Kânî, Kaside-i Münferice tercümesini, kelime kelime olmamakla birlikte aslına uygun olarak yapmaya özen göstermiştir.

\section{İşteddâezmetü teferrüci \\ Kad üzine leylüke bi'l-yelici \\ Lâ-büd gam olur bir gün gidici \\ Gice soñına gündüz gelici \\ Mutlaka gam bir gün gider ve geceden sonra gündüz gelir}

beytiyle başlayan kasidenin manzum tercümesinde gam, sıkıntı, bela ve kederlerin mutlaka bir gün yok olup gideceğinden, her geceden sonra mutlaka gündüzün geleceğinden, karanlık gecelerin yıldızları olsa da sonunda güneşin doğacağından söz edilerek insanoğlunun yaşadığı zorluklara ve sıkıntılara karşı sabırla göğüs germesi gerektiğine işaret edilmektedir. Kâinattaki her varlık Allah'ın kudret elinden çıktığı için ona râm olunmalı, Allah'ın ikramlarının bolluğu, bereketli yağmurlar gibi ardı arkası kesilmeden devam etmektedir. Dünyaya tamah edilmemesi uyarısıyla asıl ahiret hayatının öne çıkarıldığı, dünya ve ukbânın alçak ve yüksek zıtlıklarıyla sunulmaktadır. Gönül pınarı taştıkça feyiz deryaları coşacağından nefsani arzulardan sıyrılarak gönüllere girecek nimetlerin bolluğundan feyz alınmalıdır. İnsanoğlunun özüyle sözünün bir olması, yaptıklarının hesabını bir gün vereceği bilinciyle hayata sarılması, kendisine sunulan ilahi lütuflara mazhar olması, aklını kullanarak kâinatı anlamaya çalışması, amel-i salih ve takva ile dünya hayatına yönelmesi ve kulluğu arzulaması, zengin-fakir herkesin Allah'ın kudret elinde olduğu, her şeyin yaratıcısı ve sahibi olan Allah' ın dilediğini dilediğine verdiği, dilediğinden dilediğini aldığg ve bunun hikmetinin gereği olduğu bilinciyle kaza ve kadere rıza göstermenin akıllı kişilerin kârı olacağı, hidayet kapısının öneminin bilinmesi, ruhi olgunluğun ve ilahi derecelerin saadet kapılarını araladığı, amel-i sâlihe önem verilmesi ve gaflet uykusundan uyanılması, ibadet ve taatla nur ve ziyanın parladığı, insanın günahlarını düşünerek mahzun olması ve pişmanlıkla tövbe etmesinin önemi, Kur'an-ı Kerim'in manasının düşünülerek teheccüdlerde okunması ve Allah'ın emir ve yasaklarının anlaşılması ve yaşanması, nefis ve şeytana muhalefet edilmesi, asıl gülmenin ahirette fayda sağlayacağı ve bu yüzden de Allah'ın kitabı, Rasulünün sünnetine bağlı 
kalmanın önemi üzerinde durularak Peygambere, ehline ve ashabına dua ve niyazla kaside sona ermektedir.

Kaside-i Münferice'nin manzum tercümeleri yanında yapılan Türkçe şerhlerinde anlam dünyasına yönelik detaylı izahların yapıldı̆̆ı da görülmektedir. Çakmaklığlu (2017) konuyla ilgili araştırmasında Münferice Kasidenin en meşhur şârihlerinden birisinin İsmail Rusûhî Ankaravî olduğunu belirterek Ankaravî́nin aslında ana konusu itibarıla tasavvufi bir muhtevaya sahip olmayan Kasidetü'l-Münferice adlı şiiri şerh ederken sûfî kimliği ve tasavvufi eserleri şerh etmedeki mahareti sebebiyle şiire tasavvufi bir muhteva yerleştirdiğini belirtmektedir (Çakmaklığlu, 2017:473).

\section{Nahvî'nin: \\ Ve sehâbü'l-hayri lehâ matarun Fe izâ câe'l-ebbânu teciyyin}

Kânî'nin

Hayırlı olur yağmurl bulut Vaktiyle turur her şey gelici

beytinden hareketle Ankaravî, zamanı geldiğinde rahmet yağmurlarının yağarak bütün canlıların sıkıntılarını giderip onlara hayat verdiği gibi manevi yağmurların da gönülleri rahatlatıp onlara hayat vereceğini tasavvufi bir yaklaşımla izah etmektedir. Manevi semadan kalplere inen füyâzâtın da sufilerce sembolik olarak yağmur olarak görüldüğüne işaret eden Ankaravî, insanın manevi idrak yetilerine ve latifelerine yönelik beş çeşit manevi yağmurdan söz etmektedir: Nefse yağan hidayet yağmuru itaat ve vefayı, lisana yağan fesahat yağmuru Allah'a şükür ve senayı, kalbe yağan azamet yağmuru sıdk ve safayı, ruha yağan ihlas yağmuru rü'yet ve likâyı, sırra yağan esrar yağmuru muhabbet ve şevk lütuflarını yeşertip büyütmektedir (Çakmaklığlu, 2017:469-470).

\section{Sonuç}

İbnü'n-Nahvînin Kaside-i Münfericesi ekseninde oluşan edebi gelenek bir bütün olarak değerlendirildiğinde kaside, İslam coğrafyasında yaygın kabul görmesinin sonucu olarak klasik Türk edebiyatında da ilgi çeken bir manzume olarak tanınmıştır. Kasidenin farklı dönemlerde çeşitli tercüme, şerh ve tahmislerinin yapılmış olması bu ilginin kanıtı niteliğindedir. Gam, gussa ve kederden kurtuluşa vesile olduğuna inanılan kaside ile ilgili oluşan geleneksel ritüellerin yaygınlık kazanmasındaki etkisi de göz önüne alındı̆̆ında kasidenin dini mimari ve İslami edebiyatlardaki etki değeri giderek artmıştır. Faklı dönemlerde pek çok şair ve şârih tarafından da ele alınan kasidenin XVIII. yüzyıl şairlerinden Ebu Bekir Kânî tarafından da tercümesinin yapılarak divanında yer almış olması divan şairlerinin ortak İslam kültürüne sirayet eden mevzulara duyarlı oluşunun bir göstergesi olması açısından da ayrıca önem arz etmektedir.

\section{Kaynakça}

Alkan, Ercan (2012). "Es'ad Erbilî’nin Tercüme-i Kaside-i Münferice Adlı Eseri”, Tasavvuf Dergisi, İstanbul, XXX, s. 151-172.

Atik, Necmi (2018). Antalya Kaleiçi Tekeli Mehmet Paşa Camii Münferice Kasidesi, İlahiyat Araştırmaları Dergisi, S.10, s.15-47 
Çakmaklığlu, M. Mustafa (2017). “İsmail Rusûhî Ankaravî’nin El-Hikemü'l-Münderice fi Şerhi'l-Münferice Adlı Şerhi ve Tasavvufî Muhtevası", II. Uluslararası Hacı Bayram-ı Velî Sempozyumu Bildiriler Kitabı, Ankara: Kalem Neşriyat, s.2461-474

Durmuş. İ; Elmalı, H. (2000). “İbnu’n-Nahvî”, TDV İslam Ansiklopedisi, İstanbul: C.21, s.164.

Elmalı, Hüseyin (2002). “İbnu'n-Nahvî, el-Kasidetu'l-Münferice'si ve Tercümesi” Dokuz Eylül Üniversitesi İlahiyat Fakültesi Dergisi, İzmir, XVI, s. 37-41.

Yazar, İlyas (2010). Kânî Dîvânı Tenkidli Metin ve Tahlil. İstanbul: Libra Yay.

Yıldırım, Yusuf (2015) "Salâhî-i Uşşâkî'nin Manzum Kaside-i Münferice Tercümesi", Cumhuriyet Üniversitesi İlahiyat Fakültesi Dergisi, c. XIX, Sayı: 1 s. 88-108 


\section{EK-1: Kaside-i Münferice, Tercümesi ve Diliçi Çevirisi}

\begin{tabular}{|c|c|c|c|}
\hline & Nahvî’nin Kaside-i Münfericesi & Kânî'nin Kaside-i Münferice Tercümesi & Diliçi Çevirisi \\
\hline 1. & $\begin{array}{l}\text { İşteddā ezmetü teferrüci } \\
\text { Kad üzine leylüke bi'l-yelici }\end{array}$ & $\begin{array}{l}\text { 1. Lā-büd gam olur bir gün gidici } \\
\text { Gice șoñına gündüz gelici }\end{array}$ & $\begin{array}{l}\text { 1. Mutlaka gam bir gün gider ve geceden sonra } \\
\text { gündüz gelir. }\end{array}$ \\
\hline 2. & $\begin{array}{l}\text { Ve zalāmü'lleyli lehā serecün } \\
\text { Hattā yegsşāhu Ebu's-Sereci }\end{array}$ & $\begin{array}{l}\text { 2. Muẓlim gicede yılduzlar olur } \\
\text { Șoñunda güneş oldı tọgıcı }\end{array}$ & $\begin{array}{l}\text { 2. Karanlık gecelerin yıldızları olsa da sonunda } \\
\text { güneş doğar. }\end{array}$ \\
\hline 3. & $\begin{array}{l}\text { Ve sehābü'l-ḩayri lehā mațarun } \\
\text { Fe izā cāe'l-ebbānu teciyyin }\end{array}$ & $\begin{array}{l}\text { 3. Hayırlı olur yaġmurlı bulut } \\
\text { Vaḳtiyle țurur her şey gelici }\end{array}$ & $\begin{array}{l}\text { 3. Yağmur bulutlar hayırlı olur ve gelen her şey } \\
\text { vakti geldiğinde durur. }\end{array}$ \\
\hline 4. & $\begin{array}{l}\text { Ve fevāidü mevlānā cemelün } \\
\text { Li-sürūci'l-enfüsi ve'l-mehici }\end{array}$ & $\begin{array}{l}\text { 4. Çoḳdur ni'amı Haḳkuñ kim odur } \\
\text { Nefsüñ göñlüñ yolın açıcı }\end{array}$ & $\begin{array}{l}\text { 4. Nefsin ve gönüllerin yolunu açacak Hakk'ın } \\
\text { nimetleri çoktur. }\end{array}$ \\
\hline 5. & $\begin{array}{l}\text { Ve lehā erecün maḥyün ebeden } \\
\text { Fa'kṣud maḥyen zāke'l-ereci }\end{array}$ & $\begin{array}{l}\text { 5. Şol būy-ı hayāt göñülde olur } \\
\text { Bul anı da ol dirlik bulıcı }\end{array}$ & $\begin{array}{l}\text { 5. İnsana dirlik ve huzur veren gönüldeki şu } \\
\text { hayatın kokusunu bul. }\end{array}$ \\
\hline 6. & $\begin{array}{l}\text { Fe li-rabbetin mā fāża'l-mahyā } \\
\text { Bi-buhūri'l-mevci mine'llüceci }\end{array}$ & $\begin{array}{l}\text { 6. Çoḳ kerre țaşar göñül șuları } \\
\text { Deryālar olur feyżin dökici }\end{array}$ & $\begin{array}{l}\text { 6. Gönül suları çoğu zaman taşarak feyzin } \\
\text { döküldüğü deryalar olur. }\end{array}$ \\
\hline 7. & $\begin{array}{l}\text { Ve’l-ḩalḳu cemi'an fī yedihi } \\
\text { Fe żū vāsi'atin ve żevū ahreci }\end{array}$ & $\begin{array}{l}\text { 7. Kudret yedine munḳat ḳamusı } \\
\text { Vüs'at bulıcı muḥāa olıcı }\end{array}$ & $\begin{array}{l}\text { 7. Gücü olan da muhtaç olan da hepsi Hakkın } \\
\text { kudret eli karşısında boyun eğer. }\end{array}$ \\
\hline 8. & $\begin{array}{l}\text { Ve nezū lehüm ve țulū'ahüm } \\
\text { Fe 'alā derekin ve 'alā dereci }\end{array}$ & $\begin{array}{l}\text { 8. Dünyā diyilen alçaḳda olur } \\
\text { 'Uḳbā diyilen yüce olıcı }\end{array}$ & $\begin{array}{l}\text { 8. Dünyaya tamah eden alçakta olurken ahireti } \\
\text { önemseyen yüksekte olur }\end{array}$ \\
\hline 9. & $\begin{array}{l}\text { Ve me‘āyişihüm ve 'avāḳıbühüm } \\
\text { Leyse fi'l-meşiyyi 'alā 'iveci }\end{array}$ & $\begin{array}{l}\text { 9. Dünyā işi hem 'uḳbā işi hem } \\
\text { Egrüligiyle olmaz olıcı }\end{array}$ & $\begin{array}{l}\text { 9. Hem dünya hem ahiret işi eğrilikle bir arada } \\
\text { olmaz }\end{array}$ \\
\hline 10. & $\begin{array}{l}\text { Hükmün nüsicet bi-yedi hịmetin } \\
\text { Sümme intesecet bi'l-müntesici }\end{array}$ & $\begin{array}{l}\text { 10. Ṭoḳındı niẓām üzre bu cihān } \\
\text { Hikmet yedidür çün toḳıyıcı }\end{array}$ & $\begin{array}{l}\text { 10. Yaratıcının hikmet elinde olan bu dünya } \\
\text { belirli kurallar üzerine kuruldu. }\end{array}$ \\
\hline 11. & $\begin{array}{l}\text { Fe-iz̄ā iḳteșadet sümme'l-'aracet } \\
\text { Fe bi-muḳtașıdi ve bi-mün'arici }\end{array}$ & $\begin{array}{l}\text { 11. Luṭ̂ eylese yā ḳahr eylese ger } \\
\text { Kendü țalebüñle olur idici }\end{array}$ & $\begin{array}{l}\text { 11. Kişi yaptıklarıyla Hakkın ya lütfuna erer ya } \\
\text { da kahrına uğrar. }\end{array}$ \\
\hline 12. & $\begin{array}{l}\text { Şehidet bi-'acāyibihā ḥucacun } \\
\text { Kāmet bi'l-emri 'ale'l-ḥucaci }\end{array}$ & $\begin{array}{l}\text { 12. Hikmetlerine şāhid bu cihān } \\
\text { Emriyle gelür yıllar geçici }\end{array}$ & $\begin{array}{l}\text { 12. Bu dünya yıllar geçse de Hakk'ın emriyle } \\
\text { olan hikmetlere şahittir. }\end{array}$ \\
\hline 13. & $\begin{array}{l}\text { Ve raḍ̂ye bi-ḳażāi’llahi haciyyen } \\
\text { Fe 'alā merkūzetihi fe‘aci }\end{array}$ & $\begin{array}{l}\text { 13. Çü ḳażāya rıżā 'āḳil işidür } \\
\text { Ol merkeze gir olma çıkıcı }\end{array}$ & $\begin{array}{l}\text { 13. Kazaya rıza göstermek akıllı kişilerin işidir, } \\
\text { sen de onlardan ayrılma. }\end{array}$ \\
\hline 14. & $\begin{array}{l}\text { Ve ižā infetaḥat ebvāb-1 hüdā } \\
\text { Fa'cel li-ḩazāinihā velici }\end{array}$ & $\begin{array}{l}\text { 14. Feth olsa saña ebvāb-1 hüdā } \\
\text { Gir gencine ol ta'cīl idici }\end{array}$ & $\begin{array}{l}\text { 14. Hakk'ın kapıları sana açılsa o hazineye } \\
\text { girmekte acele et. }\end{array}$ \\
\hline 15. & $\begin{array}{l}\text { Ve izāa ehāvelet nihāyetihā } \\
\text { Faḥzer iz zāāke mine'l-'araci }\end{array}$ & $\begin{array}{l}\text { 15. Dirsen ireyüm hịmet șoñuna } \\
\text { Șaḳın ki aña yoḳdur irici }\end{array}$ & $\begin{array}{l}\text { 15. Hikmetin sonunu göreyim dersen ondan } \\
\text { sakın, çünkü ona eren olmadı. }\end{array}$ \\
\hline 16. & $\begin{array}{l}\text { Li-tekūne mine's-sebāḳi iz̄ā } \\
\text { Mā ci’te illā tilke'l-fereci }\end{array}$ & $\begin{array}{l}\text { 16. Ögdüñ al kim çünki olasın } \\
\text { Bu cāy-1 rıżā üzre țurıcı }\end{array}$ & $\begin{array}{l}\text { 16. Söylenenlere kulak ver ki bu riza } \\
\text { makamında kalıcı olasın. }\end{array}$ \\
\hline 17. & $\begin{array}{l}\text { Fe hünāke'l-'ayşü ve behcetühü } \\
\text { Fe li-mübtehici ve li-müntehici }\end{array}$ & $\begin{array}{l}\text { 17. Taḳvā yolına rāhi olana } \\
\text { Cennet aña mesken olıcı }\end{array}$ & $\begin{array}{l}\text { 17. Takva yolunun yolcusu olanın Cennet } \\
\text { mekânı olur. }\end{array}$ \\
\hline 18. & $\begin{array}{l}\text { Fe-hici’l-a'mālü izāā rekadet } \\
\text { Fe izaā mā heccet izāa tehici }\end{array}$ & $\begin{array}{l}\text { 18. Ṭursa binegüñ yürit 'amelüñ } \\
\text { Sürdükce olır ḳuvvet bulıcı }\end{array}$ & $\begin{array}{l}\text { 18. Salih amellerine devam et ki duran bineğin } \\
\text { yürümeye devam etsin. }\end{array}$ \\
\hline 19. & $\begin{array}{l}\text { Ve ma‘āșiya'llahu semācetühā } \\
\text { Tezdāde leži'l-ḩalḳı's-semici }\end{array}$ & $\begin{array}{l}\text { 19. 'İsyānı iden pek çirkin olur } \\
\text { Bed-hūya odur şöhret virici }\end{array}$ & $\begin{array}{l}\text { 19. Kötü huylunun şöhreti olan isyandan uzak } \\
\text { dur ki çirkin olmayasın. }\end{array}$ \\
\hline
\end{tabular}


20. Ve li-țā'atihi ve șabāḥatihā

Envāru șabāhin mübtelici

21. Men yahtabe hūūe'l-ḩuldi bihā Yaẓferu bi’l-ḥūri ve bi'l-ganici

22. Fe küni'l-marżıyyu lehā tebḳī Terżāhu gaden ve tekūnü neciyyi

23. Vetlü'l-Kur'āne bi-ḳalbin żi-huznin Ve bi-șavtin fïhi şeciyyi

24. Ve șalātü'lleyli mesāfetühā Fe'zheb fîhā bi'l-fehm veciyyi

25. Ve te'emmelühā ve me'ānihā Te'ti'l-Firdevse ve tefterici

26. Ve'şrib tesnime müferrecihā Lā mümtezicā ve bi-mümtezici

27. Medhu'l-'aḳli'l-āyetihi hüdā Ve hüve mütevellin 'anhu heciyyin

28. Ve Kitābu'llahi riyāżetihi Li-'uḳūi'l-ḩalḳı bi-münderici

29. Ve ḩıāru'l-ḩalḳı hüdātehüm Ve sivāhüm min hemeci'l-hemeci

30. Ve izaā künte'l-maḳdāmi felā Tecza'u fi'l-harbi mine'r-reheci

31. Ve ižā ebșarat menārı hedyin Fe'zhhar ferden fevka's-sebeci

32. Ve ižā iştāḳat nefsün vecedet Elemā bi'ş-şevki'l-mu'teleci

33. Ve senāyā'l-hüsnā żāhịkatün Ve tamāmu'ż-żaḥi 'ale'l-feleci

34. Ve ġyābü'l-esrāri ḳad icteme'at Bi-emānetihā taḥte'ş-şeceri

35. Ve'r-rengü yedūmu li-șāhịibihi Ve'l-ḥarḳu yeșiru ile'l-hereci

36. Șalavātu'llahi 'ale'l-mehdiyyi El-Hādi'n-nāse ile'n-neheci

37. Ve Ebī Bekrin fï sïretihi Ve lisāni maḳālātihi’l-leheci

38. Ve Ebī Hafș ve kerāmetihi Fī ḳıșșati Sāriyeti'l-hraleci

39. Ve Ebī ‘Ömerā ve Zi'n-nūreyni El-müstahyi’l-müstahyi'l-behici
20. Ṭā'atda olan pek güzel olur Hurşid-i șubh oldur olıcı

21. Uçmag̉a irer țā'atla kişi Hūruñ güzelin olur ḳoḳıcı

22. Ṭaḳvā ile sen olg̀ıl ki bugün Yārın olasın memdūḥ olıcı

23. Kur'ān oḳı yanık dil ile Șavtuñ ola kim te's̄īr idici

24. Giceyle nemāz taḳvā yolıdur Git gel o yola ol feḥm idici

25. Ma'nāsını feḥm it ki olasın Firdevse girüp mesrūr olıcı

26. Tesnīm meyini 'aynından içüp Her dürlüsini hem ol içici

27. Memdūh-1 'aḳıl toggrıca gider Mezmūmı olur yoldan șapici

28. Kưu'ān'da cemī' eşyā yazılı ‘Aḳla göredür ol añladıcı

29. Halḳuñ eyüsi Haḳk yola gider Şol gayrisidür hemcüñ hemeci

30. Çünki olasın ceng-āver-i nefs Tozdan gocınup olma ḳaçıcı

31. Hādī saña ger gösterse 'alem Ol münferiden aña çıḳıcı

32. Bir şeye nefes müştāḳ ola ger Ol şevḳle olur çoḳ gam görici

33. Mạ̣būb yüzüñe ger güle senüñ Dişler görine saña șoñ ucı

34. Esrār-1 Hुudā mestūr u emīn Ġayrı kim ola anı içici

35. Reng șāhibinini dā'im ider ol Tab'1 tiz olan oldı yanıcı

36. Haḳḳdan șalavāt ol hādiye kim Hakka bizi odur vașl idici

37. Hem Ebī Bekr olsun kim odur Șıdḳında kerāmet söyleyici

38. Dahı 'Ömer'e k'oldur cebele Ya Sāriye’yi ismā‘ idici

39. 'Ossman'a dahı ki oldur o naḳi Hașletde hayā issı olıcı
20. Salih amel işleyen sabah güneşi gibi güzel olup daima parlar.

21. Salih ameli olan Cennete kavuşur ve hurilerle birlikte olur.

22. Sen bugün takva ile Hakk'a yönel ki yarın övülen kişi olasın.

23. Gönüllere huzur veren yanık sesinle içten Kur'an oku.

24. Gece namazı takvanın yoludur, manasinı anlayarak devam et.

25. Okuduklarının manasını anla ki Cennete girip mutlu olasin.

26. Cennet şarabının her türlüsünü kaynağından kana kana iç.

27. Akıllı, övülen kişi doğru yolda ilerler, akılsız kötü kişi yoldan sapar.

28. Kur'an'da bütün her şey yazılı olup onlar akılla anlaşılabilir.

29. İnsanların iyileri Hak yolunda ilerlerken diğerlerinin bir önemi yoktur.

30. Nefsinin cengâveri olup mücadele edesin ve tozdan sakınıp kaçmayasın.

31. Eğer mürşit sana bir iz gösterirse, o izlerden birer birer doğru yolu bulasın

32. Eğer nefes bir şeyi arzulasa o şevkle çok gam ve elem görür.

33. Eğer dilber senin yüzüne gülerse dişlerinin ucu sana görünür.

34. Hakk'ın sırları gizlenmiş ve emin olduğu için kim onu açık edebilir?

35. Renk daima sahibini işaret eder, keskin tabiatlı kişi her zaman zarardadır.

36. Allah'ın rahmeti, bize doğru yolu gösteren Peygamberin üzerine olsun.

37. (Allah’ın rahmeti) Doğruluk ve cömertlik timsali Ebu Bekir üzerine olsun.

38. (Allah'ın rahmeti) Sâriye kıssasında kerameti zahir olan Ömer üzerine olsun.

39. (Allah'ın rahmeti) takva sahibi, kendisinden hayâ edilen Osman üzerine olsun. 
40. Ve Ebī Ḥasan fi'l-'ilmi izaà Vāfī bi-sehāibihi'l-haleci

41. Ve 'ale's-sebține ve ümmetihā Ve cemi' 'i'l-ālì bihim telici

42. Ve 'ale'l-așhāābi bi-cümletihim Bezelu'l-emvāli me'a'l-meheci

43. Yā Rabbi bihim ve bi-‘ālihim Ve 'accele'n-nașru ve bi'l-fereci
40. Dahı 'Ali’ye kim ol veliye

‘İlmi șuyına ‘ālem ḳanıcı

41. Ḥasaneynine hem Fāṭıma'ya Hep āline tā bize gelici

42. Așhāābına hep olsun ki olar Ḥaḳk yolına māl hem cān virici

43. Yā Rabb olaruñ hürrmetlerine Ta'cīlile vir nașr u fereci
40. (Allah'ın rahmeti) ilmiyle âlemin kapısı ol veli Ali üzerine olsun.

41. (Allah'ın rahmeti) Fatıma, Hasan, Hüseyin ve âli ashabı üzerine olsun.

42. (Allah'ın rahmeti) hak yolunda canlarını ve mallarını feda eden ashabı üzerine olsun.

43. Ya Rabbi onların hürmetine bizlere yardım et ve sıkıntılarımızdan bizleri acilen kurtar. 


\section{EK-2: Kaside-i Münferice, Kânî Divanı Köprülü 475:30-32}

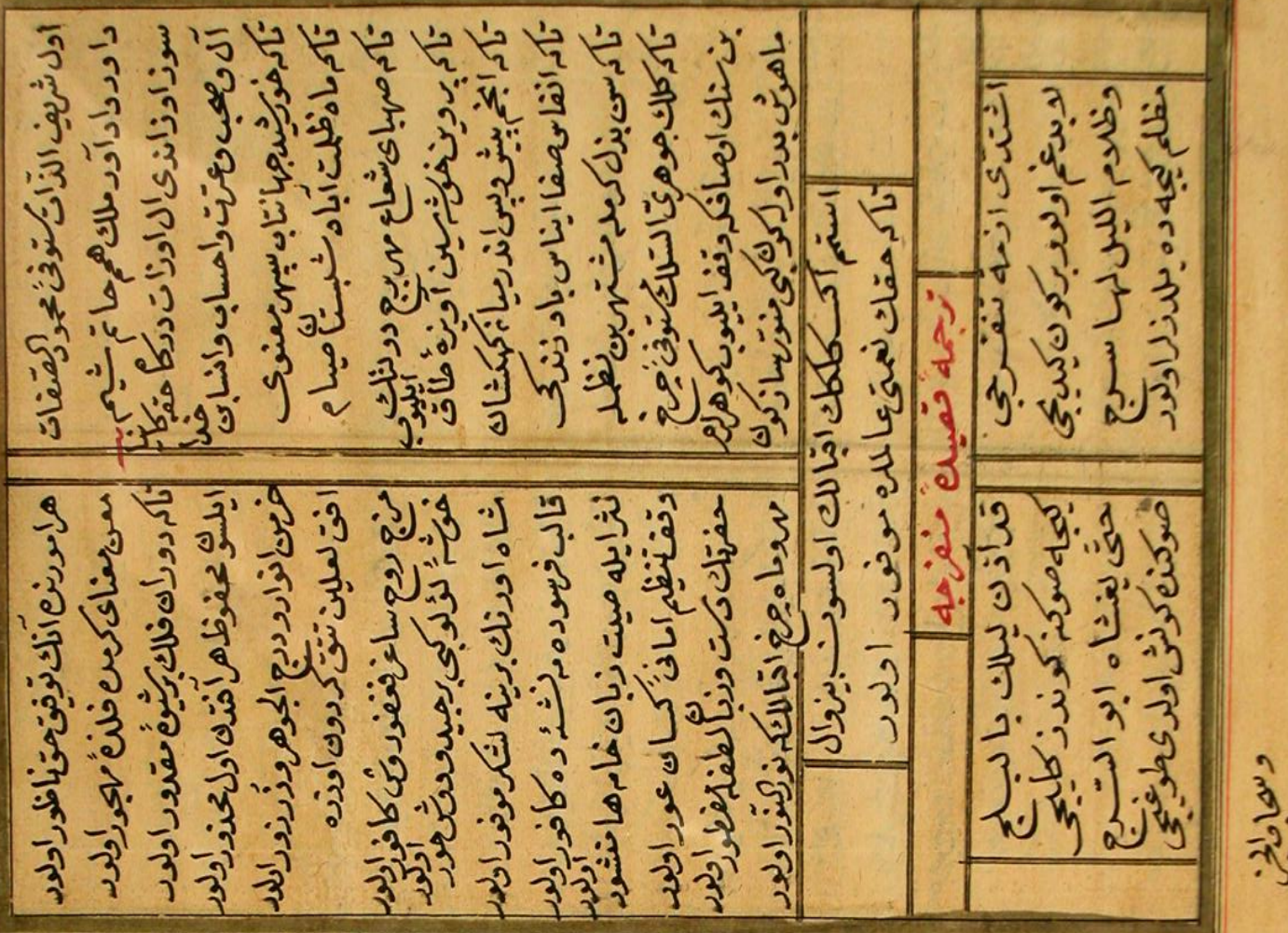

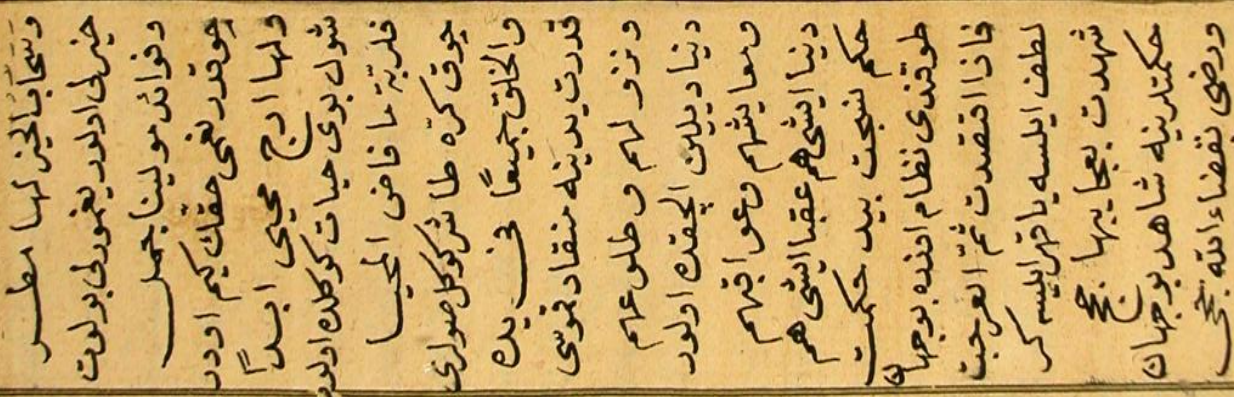

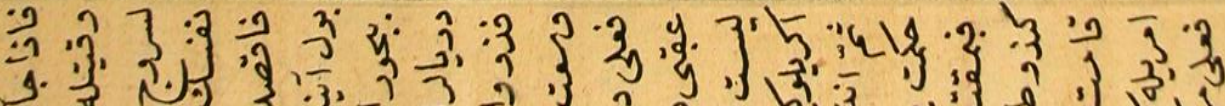

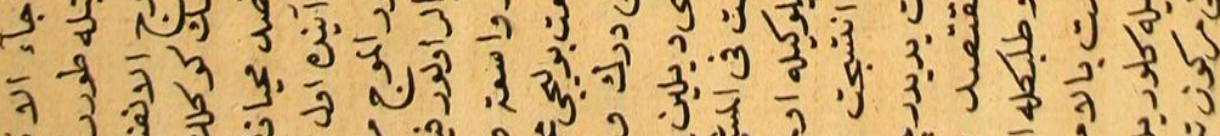

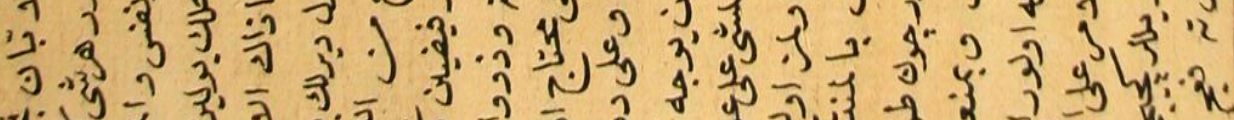

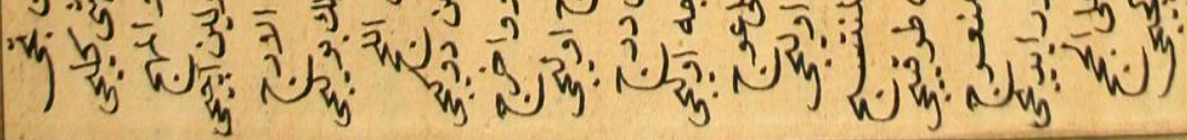




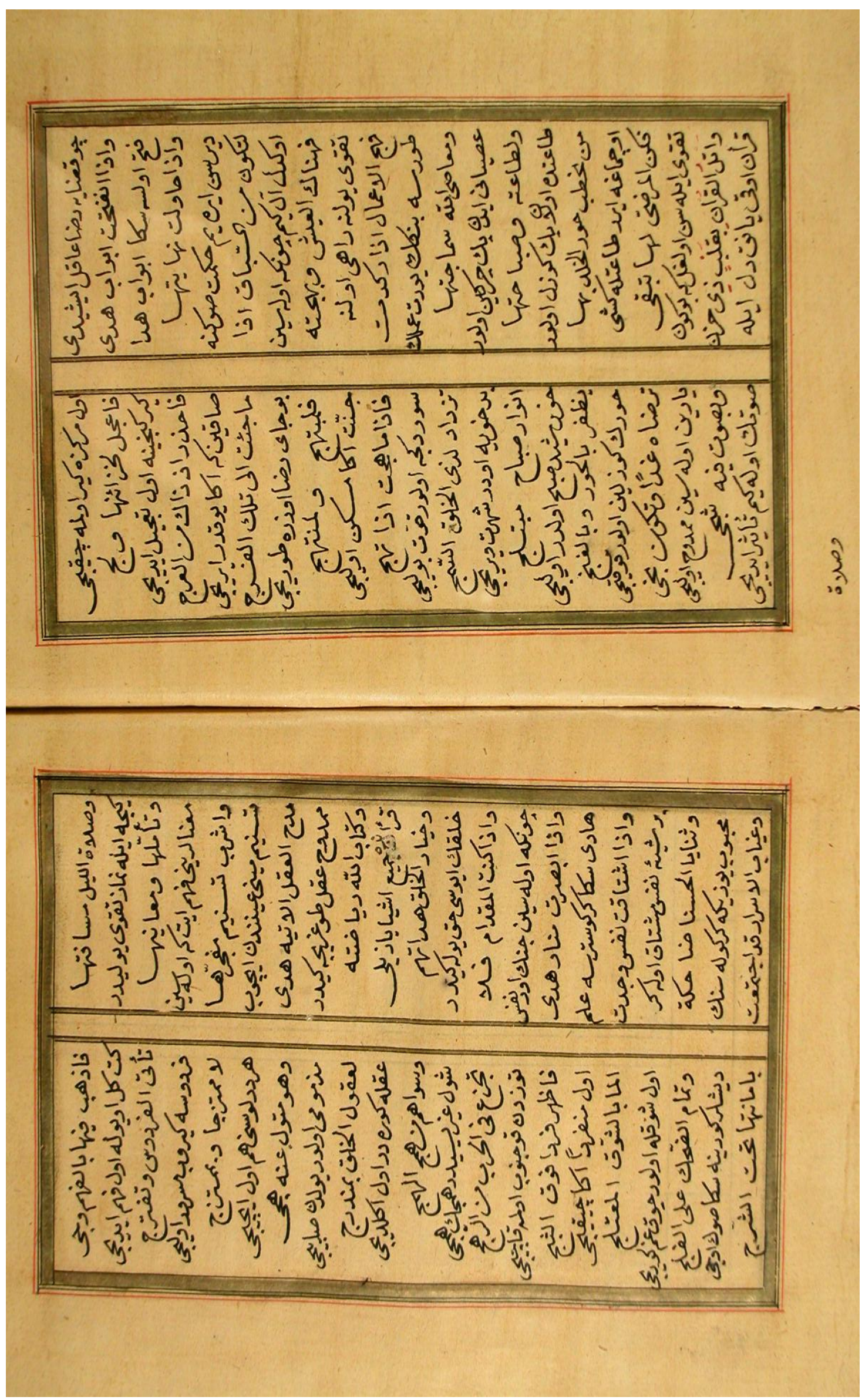



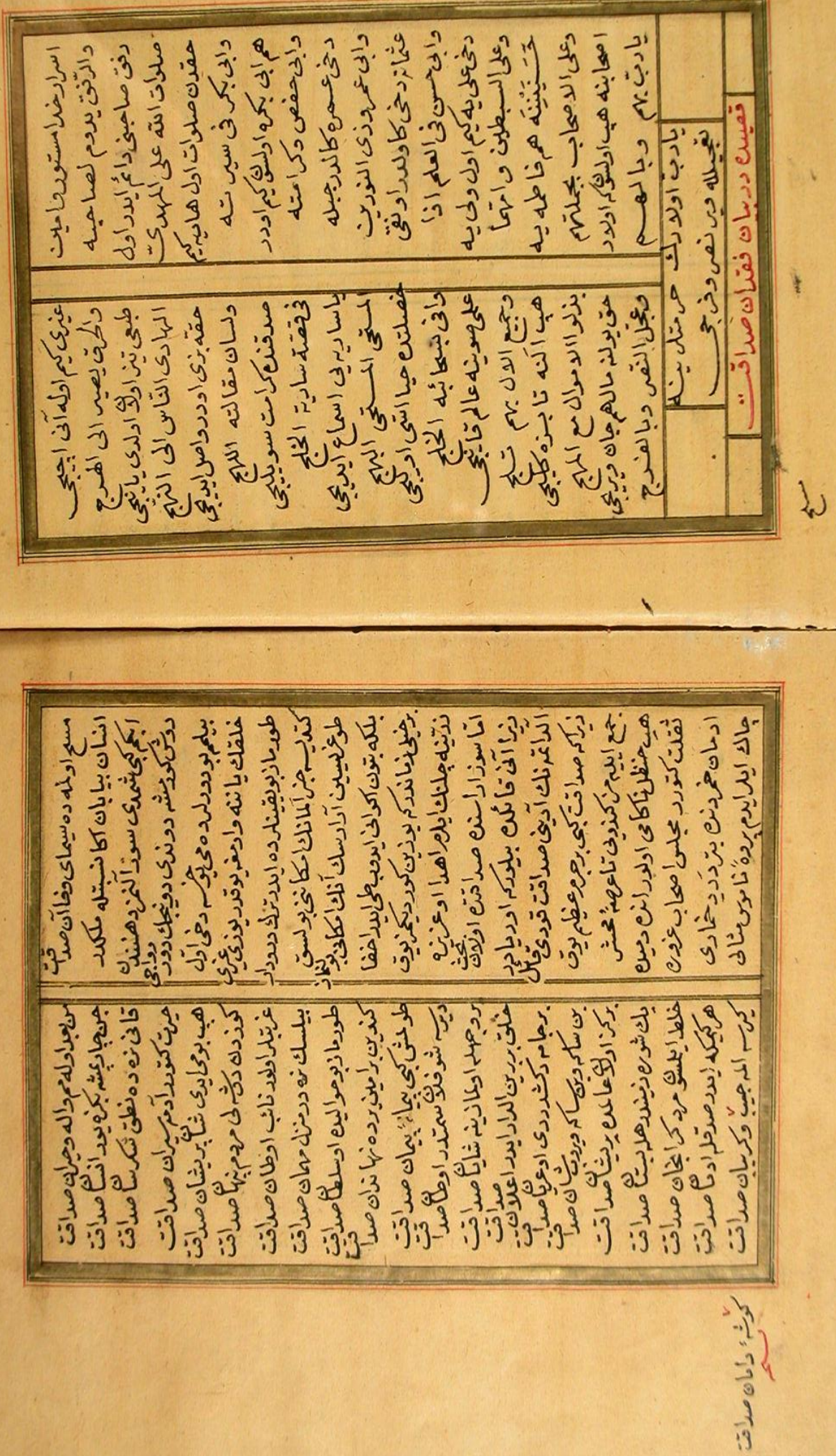